\title{
Injuries to pedal cyclists on New Zealand roads, 1988-2007
}

Sandar Tin $\operatorname{Tin}^{1 * \dagger}$, Alistair Woodward ${ }^{2 \dagger}$, Shanthi Ameratunga ${ }^{1+}$

\begin{abstract}
Background: The risk of injury is one of the major barriers to engaging in cycling. We investigated exposure-based rates and profiles of traffic injuries sustained by pedal cyclists that resulted in death or hospital inpatient treatment in New Zealand, one of the most car dependent countries.

Methods: Pedal cyclist traffic injuries were identified from the Mortality Collection and the National Minimum Dataset. Total time spent cycling was used as the measure of exposure and computed from National Household Travel Surveys. Analyses were undertaken for the periods 1988-91, 1996-99 and 2003-07 in relation to other major road users and by age, gender and body region affected. A modified Barell matrix was used to characterise the profiles of pedal cyclist injuries by body region affected and nature of injury.

Results: Cyclists had the second highest rate of traffic injuries compared to other major road user categories and the rate increased from 1996-99 to 2003-07. During 2003-07, 31 injuries occurred per million hours spent cycling. Non-collision crashes (40\%) and collisions with a car, pick-up truck or van (26\%) accounted for two thirds of the cycling injuries. Children and adolescents aged under 15 years were at the highest risk, particularly of non-collision crashes. The rate of traumatic brain injuries fell from 1988-91 to 1996-99; however, injuries to other body parts increased steadily. Traumatic brain injuries were most common in collision cases whereas upper extremity fractures were most common in other crashes.
\end{abstract}

Conclusions: The burden of fatal and hospitalised injuries among pedal cyclists is considerable and has been increasing over the last decade. This underscores the development of road safety and injury prevention programmes for cyclists alongside the cycling promotion strategies.

\section{Background}

The popularity of cycling as a sport and recreation activity has increased in New Zealand over recent years $[1,2]$. In 2006, for the first time, more bicycles were imported into the country than cars $[3,4]$. However, a bicycle is rarely used as a mode of transportation and represents only $2 \%$ of total travel time [5]. The proportion of commuters using a bicycle has been declining since 1986 and less than $3 \%$ of the employed population cycled to work in 2006 [6]. The largest decline was observed among younger age groups and females $[6,7]$.

One of the major barriers to engaging in cycling is the real and perceived risk of injury $[8,9]$. The most recent

\footnotetext{
* Correspondence: s.tintin@auckland.ac.nz

† Contributed equally

'Section of Epidemiology and Biostatistics, School of Population Health,

University of Auckland, Auckland, New Zealand

Full list of author information is available at the end of the article
}

(2008) data from the Ministry of Transport, based on police reports, showed that ten cyclists were killed, 186 were seriously injured and many more suffered minor injuries due to police-reported crashes on public roads [10]. The estimated total social cost was approximately NZ\$224 million [10]. However, these figures are unlikely to represent an accurate profile of cycling injuries because it is not clear how "serious injury" was defined, and crashes are generally reported to the police only if a motor vehicle is involved. Langley and colleagues found that only $22 \%$ of cyclists admitted to hospital following a crash on public roads appeared in the police crash data [11].

Earlier research using the mortality and hospitalisation data showed a decline in cycling injuries involving a collision with a motor vehicle from 1989 to 1998 [12]. This paper aimed (1) to assess exposure-based rates of onroad injuries to pedal cyclists that resulted in death or
C Biomed Central 
hospital inpatient treatment over the period 1988-2007, (2) to quantify differences in such rates in relation to other road users and by age, gender and body region affected, and (3) to describe cycling injury profiles using a modified Barell matrix [13].

\section{Methods}

\section{Data sources}

The data for this analysis were obtained from the National Minimum Dataset and the Mortality Collection maintained by the Ministry of Health's Information Directorate, and the Household Travel Survey Dataset maintained by the Ministry of Transport. Specific approval was not sought as the data were publicly available upon request and only anonymous data were used for all analyses.

\section{National Minimum Dataset}

This includes information about all day patients and inpatients discharged from all public hospitals and over $90 \%$ of private hospitals in New Zealand. The data collected include demographic information, diagnoses and diagnostic and therapeutic procedures. For all injury discharges, the circumstances of injury are coded according to the external causes of injury and poisoning codes ( $\mathrm{E}$ codes) and the nature of injury is coded according to the International Classification of Diseases (ICD) [14]. ICD9-CMA was used before July 1999 and ICD-10-AM afterward. It was reported that $5 \%$ of the principal diagnosis and $18 \%$ of the first four digits of the E-codes for hospital discharges during 1996-98 that were coded under ICD-9$\mathrm{CM}$ and $14 \%$ of the principal diagnosis and $26 \%$ of the Ecodes for hospital discharges during 2001-04 that were coded under ICD-10-AM were incorrect $[15,16]$.

\section{Mortality Collection}

This includes information about all deaths registered in New Zealand from 1988 onwards. The data collected include demographic information and the underlying cause of death coded according to the ICD [14]. ICD-9CMA was used before 2000 and ICD-10-AM afterward. Overseas research suggested that the inaccuracies of coding could be greater for death records compared to hospital discharge records, particularly among older people [17-19]; however, there is insufficient evidence in New Zealand to confirm this.

\section{Household Travel Surveys}

The three separate national surveys [20] collected information on daily personal travel, with the sampling frame comprising all residents (including children) in private dwellings in New Zealand. The entire survey methodology was piloted. The survey questions were developed for the New Zealand Ministry of Transport by AMPT Applied Research Pty Ltd (Sydney) and pretested on households from a range of socio-economic backgrounds.
The first survey was undertaken between 1 July 1989 and 30 June 1990 and included 8,719 people aged five and over. The second survey was carried out between 1 July 1997 and 30 June 1998 and included over 14,250 people of all ages. From 1 August 2003, an ongoing survey has been conducted each year, with the sampling frame comprising approximately 2,000 households (resulting in responses from about 3500 people) per year. Up to 30 June 2009, 25,471 people have participated in the third survey.

Full response rates (i.e., the percentage of eligible households in which all members participated fully in the survey) were $75 \%, 75 \%$ and $66 \%$ respectively for the first, second and third surveys and full and partial response rates (i.e., the percentage of eligible households in which one or more members participated fully in the survey) were $78 \%, 79 \%$ and $71 \%$ respectively.

In each survey, travel time was assessed by asking respondents to keep a record of the times and places of all their travel over a specified two-day period. Departure and arrival times of each trip leg were recorded, along with trip destination, travel mode and purpose. The use of a two-day travel period minimises respondent burden and reliance on memory, compared to using a week-long period. Shortly after the conclusion of the two-day period, an interviewer questioned each respondent about their travel using the travel record as a memory aid. Interviewers were trained to prompt the respondent to recall any trips (particularly short trips) which may not have been recorded on their memory jogger.

\section{Statistical Analysis}

The rate of traffic injuries to pedal cyclists resulting in death or hospital inpatient treatment was calculated using the equation:

$$
\text { Injury rate }=\frac{\text { Total number of cases of cycling injuries per year }}{\text { Total time spent cycling (million hours) per year }}
$$

The annualised total time spent cycling was used as the measure of exposure and computed from the three travel surveys, covering the periods: 1 July 1989-30 June 1990, 1 July 1997-30 June 1998 and 1 August 2003-30 June 2008. The data were weighted to account for clustering by household and non-response to the survey.

Traffic injuries (i.e., injuries occurring on a public highway) among pedal cyclists were identified using the E-codes (ICD-9-CM: E810-819.65, E826.15, E826.95, E829-829.15; and ICD-10-AM: V10-18.3-9, V19.4-6, V19.9) [14]. The hospitalised sample was restricted to inpatient discharges from public hospitals as the majority of patients (over 97\%) requiring acute inpatient treatment for injury are admitted to public hospitals [21-23]. 
In order to enhance the validity of the analyses, the inclusion criteria included: (a) patients with a principal diagnosis of injury only (ICD-10-AM: S00-T78), (b) patients admitted to hospital for one day or more and (c) first admissions only [22]. Cases aged under five years were excluded from the overall sample as they were not surveyed in the 1989/90 travel survey. The annualised numbers of cycling injuries were computed for the periods 1988-91, 1996-99 and 2003-07 to stabilise small cell sizes.

Traffic injuries to pedal cyclists were sub-classified according to the mechanism of injury into (a) a collision with a motor vehicle (ICD-9-CM: E810-819.6; ICD-10AM: V12-V14.3-9, V19.4-6) and (b) others. For injuries that occurred between 2003 and 2007, more detailed mechanism as mentioned in the ICD-10-AM was reported.

Injury rates and $95 \%$ confidence intervals were presented in relation to other major road users (car/van drivers, ca/van passengers, motorcyclists and pedestrians) and by age, gender and body region affected. Based on the assumption that the number of injuries had a Poisson distribution, the confidence intervals were calculated by using the normal approximation (if number of injuries was more than 20 per year) or the exact probability function (if the number of injuries was 20 or less per year) [24].

A modified form of the Barell matrix was used to characterise the profiles of pedal cyclist injuries that occurred between 2003 and 2007 by body region affected and nature of injury. The Barell matrix comprises 36 body region rows and 12 nature of injury columns and places each injury ICD-9-CM code in a unique cell location [13]. For this analysis, the ICD-10-AM codes were mapped into the ICD-9-CM codes and classified into seven body regions - traumatic brain injury, other head, face and neck, spine and back, torso, upper extremity, lower extremity and others - and six injury natures - fracture, dislocation/sprains and strains, internal, open wound, contusion/superficial and others. The "multiple injury profiles" approach [25-27] was used and up to ten diagnoses per case were extracted from the dataset.

To ensure an adequate sample size, analyses were undertaken for all deaths and hospitalisations. A further analysis restricted the cases of interest to those with serious injuries defined as an injury resulting in a significant threat to life (i.e., consistent with an Abbreviated Injury Scale (AIS) $[28,29]$ score of 3 or more) in order to minimise the effect of extraneous factors such as service utilisation in assessing trends [19]. The mapping to this AIS threshold was achieved using the Barell matrix categorisation [30]. SAS (release 9.1, SAS Institute Inc., Cary, NC) and Microsoft Office Excel 2003 were used for all analyses.

\section{Results}

During 2003-07, 31 injuries occurred per million hours spent cycling; $20 \%$ had a serious injury suggesting a significant threat to life, consistent with an estimated AIS score of 3 or more (Table 1). Of the major road user categories, the injury rate for pedal cyclists was surpassed only by motorcyclists. The cycling injury rate fell from 1988-91 to 1996-99 and rose afterward; similar but less pronounced trends were observed when the sample was restricted to those with serious injuries and to those involved in a collision with a motor vehicle (Table 2). In contrast, a declining trend in injury rates was observed among other road users (Table 1).

The most common mechanisms of cycling injuries that occurred between 2003 and 2007 were non-collision crashes $(40.4 \%$ of all cases and $33.6 \%$ of cases with serious injuries) and collisions with a car, pick-up truck or van $(25.5 \%$ of all cases and $38.5 \%$ of cases with serious injuries) (Table 3).

The highest rate of cycling injuries was observed among the 5-14 year olds (Figure 1). In this age group, from 1996-99 to 2003-07, there was a substantial increase in injury risk from crashes not involving a motor vehicle. However, this trend was not observed when analyses were restricted to those with serious injuries. Males had a higher rate of collision and other injuries compared to females (Figure 2).

Compared to 1988-91, rates of traumatic brain injuries were lower in 1996-99 and 2003-07 (Figure 3). In contrast, there was an increasing trend over time in rates of injuries to other body parts. During 2003-07, the commonest injuries in crashes involving a collision with a motor vehicle were traumatic brain injuries (29.1\%), open wounds in the head, face or neck $(26.3 \%)$ and fractures in upper and lower extremities $(25.9 \%$ and $24.7 \%$ respectively) (Table 4). In cycling injuries unrelated to motor vehicle collision, upper extremity fractures (40.3\%) were most common, followed by open wounds in the head, face or neck and traumatic brain injuries (16.9\% and $14.9 \%$ respectively). Traumatic brain injuries, lower extremity fractures and open wounds in the head, face or neck occurred in $28.2 \%, 19.2 \%$ and $18.7 \%$ respectively of cases with serious injuries (Table 5).

\section{Discussion}

Our analysis showed that cyclists had the second highest rate of traffic injuries resulting in death or hospital inpatient treatment compared to other major road user categories when analysed in relation to time spent travelling. The cycling injury rate increased from 1996-99 to 200307. Non-collision crashes and collisions with a car, pickup truck or van were responsible for about two-thirds of cycling injury deaths and hospitalisations during 
Table 1 Annual numbers and rates of traffic injuries that resulted in death or hospital inpatient treatment

\begin{tabular}{|c|c|c|c|c|c|c|}
\hline \multirow[b]{2}{*}{ Mode of travel } & \multicolumn{3}{|c|}{ Annual number of injuries } & \multicolumn{3}{|c|}{$\begin{array}{l}\text { Annual number of injuries per million hours spent travelling } \\
\qquad(95 \% \mathrm{Cl})\end{array}$} \\
\hline & $1988-91$ & 1996-99 & 2003-07 & $1988-91$ & 1996-99 & 2003-07 \\
\hline \multicolumn{7}{|l|}{ Overall } \\
\hline Cyclists & 941 & 512 & 682 & $\begin{array}{c}25.61 \\
(23.97,27.25)\end{array}$ & $\begin{array}{c}21.38 \\
(19.53,23.23)\end{array}$ & $\begin{array}{c}30.74 \\
(28.43,33.04)\end{array}$ \\
\hline Car/van driver & 2081 & 2051 & 1714 & $\begin{array}{c}4.24 \\
(4.06,4.42)\end{array}$ & $\begin{array}{c}3.22 \\
(3.08,3.36)\end{array}$ & $\begin{array}{c}2.10 \\
(2.00,2.20)\end{array}$ \\
\hline Car/van passenger & 1568 & 1428 & 1086 & $\begin{array}{c}5.64 \\
(5.36,5.92)\end{array}$ & $\begin{array}{c}4.67 \\
(4.43,4.91)\end{array}$ & $\begin{array}{c}2.89 \\
(2.71,3.06)\end{array}$ \\
\hline Motorcyclist & 1655 & 895 & 784 & $\begin{array}{c}185.14 \\
(176.22,194.06)\end{array}$ & $\begin{array}{c}161.77 \\
(151.18,172.37)\end{array}$ & $\begin{array}{c}107.64 \\
(100.11,115.17)\end{array}$ \\
\hline Pedestrian & 743 & 638 & 471 & $\begin{array}{c}4.29 \\
(3.98,4.60)\end{array}$ & $\begin{array}{c}3.40 \\
(3.14,3.67)\end{array}$ & $\begin{array}{c}2.38 \\
(2.17,2.60)\end{array}$ \\
\hline \multicolumn{7}{|c|}{ Serious injuries $(A I S \geq 3$ ) } \\
\hline Cyclists & 377 & 117 & 138 & $\begin{array}{c}10.27 \\
(9.23,11.30)\end{array}$ & $\begin{array}{c}4.86 \\
(3.98,5.75)\end{array}$ & $\begin{array}{c}6.24 \\
(5.21,7.28)\end{array}$ \\
\hline Car/van driver & 886 & 774 & 629 & $\begin{array}{c}1.81 \\
(1.69,1.93)\end{array}$ & $\begin{array}{c}1.22 \\
(1.13,1.30)\end{array}$ & $\begin{array}{c}0.77 \\
(0.71,0.83)\end{array}$ \\
\hline Car/van passenger & 643 & 516 & 367 & $\begin{array}{c}2.31 \\
(2.13,2.49)\end{array}$ & $\begin{array}{c}1.69 \\
(1.54,1.83)\end{array}$ & $\begin{array}{c}0.98 \\
(0.88,1.08)\end{array}$ \\
\hline Motorcyclist & 483 & 273 & 190 & $\begin{array}{c}54.05 \\
(49.23,58.87)\end{array}$ & $\begin{array}{c}49.24 \\
(43.39,55.09)\end{array}$ & $\begin{array}{c}26.11 \\
(22.40,29.82)\end{array}$ \\
\hline Pedestrian & 362 & 254 & 187 & $\begin{array}{c}2.09 \\
(1.88,2.31)\end{array}$ & $\begin{array}{c}1.36 \\
(1.19,1.52)\end{array}$ & $\begin{array}{c}0.95 \\
(0.81,1.08)\end{array}$ \\
\hline
\end{tabular}

2003-07. Children and adolescents aged under 15 years were at the highest risk of being involved in non-collision crashes although this pattern was not observed for serious injuries. The rate of traumatic brain injuries fell from 1988-91 to 1996-99; however, injuries to other body parts increased steadily. Traumatic brain injuries were most common in crashes involving a collision with a motor vehicle whereas upper extremity fractures were most common in other crashes.

The major strength of this study is the use of data from the three national datasets to quantify exposurebased rates of cycling injuries resulting in death or hospital inpatient treatment. However, some limitations should be kept in mind when interpreting the findings.

Injuries treated in emergency departments and private primary care facilities, or self-treated, were not included in this analysis. It has been proposed that such injuries be excluded in developing indicators of injury incidence due to incomplete ascertainment [19]. While such injuries may not pose a significant threat to life, it cannot be assumed that they will not pose a threat to longerterm disability. Ascertainment of relevant cases could also be affected by inaccuracies in diagnosis and external

Table 2 Annual numbers and rates of collision vs. other traffic injuries to pedal cyclists that resulted in death or hospital inpatient treatment

\begin{tabular}{|c|c|c|c|c|c|c|}
\hline \multirow[b]{2}{*}{ Mode of travel } & \multicolumn{3}{|c|}{ Annual number of injuries } & \multicolumn{3}{|c|}{$\begin{array}{l}\text { Annual number of injuries per million hours spent travelling } \\
\qquad(95 \% \mathrm{Cl})\end{array}$} \\
\hline & $1988-91$ & $1996-99$ & 2003-07 & $1988-91$ & $1996-99$ & 2003-07 \\
\hline \multicolumn{7}{|l|}{ Total } \\
\hline Collision with a motor vehicle & 349 & 185 & 189 & $\begin{array}{c}9.51 \\
(9.01,10.01)\end{array}$ & $\begin{array}{c}7.66 \\
(7.11,8.21)\end{array}$ & $\begin{array}{c}8.47 \\
(7.86,9.07)\end{array}$ \\
\hline Others & 592 & 327 & 493 & $\begin{array}{c}16.11 \\
(15.46,16.76)\end{array}$ & $\begin{array}{c}13.57 \\
(12.84,14.31)\end{array}$ & $\begin{array}{c}22.02 \\
(21.05,22.99)\end{array}$ \\
\hline \multicolumn{7}{|l|}{ Serious injuries $(A I S \geq 3)$} \\
\hline Collision with a motor vehicle & 166 & 55 & 61 & $\begin{array}{c}4.51 \\
(4.16,4.85)\end{array}$ & $\begin{array}{c}2.29 \\
(1.99,2.59)\end{array}$ & $\begin{array}{c}2.74 \\
(2.40,3.09)\end{array}$ \\
\hline Others & 211 & 62 & 78 & $\begin{array}{c}5.75 \\
(5.36,6.13)\end{array}$ & $\begin{array}{c}2.57 \\
(2.25,2.89)\end{array}$ & $\begin{array}{c}3.49 \\
(3.10,3.87)\end{array}$ \\
\hline
\end{tabular}


Table 3 Mechanism of traffic injuries to pedal cyclists that resulted in death or hospital inpatient treatment (20032007)

\begin{tabular}{lcc}
\hline Mechanism & $\begin{array}{c}\text { Overall Injuries } \\
\text { (\%) }\end{array}$ & $\begin{array}{c}\text { Serious Injuries } \\
\text { (\%) }\end{array}$ \\
\hline Collision with car, pick-up truck or van & 25.51 & 38.49 \\
Collision with heavy transport vehicle or bus & 1.79 & 5.35 \\
Collision with two- or three-wheeled motor vehicle & 0.35 & 0.58 \\
Collision with other non-motor vehicle & 0.06 & 0.00 \\
Collision with other pedal cycle & 4.11 & 5.35 \\
Collision with pedestrian or animal & 1.00 & 1.30 \\
Collision with fixed or stationary object & 5.60 & 7.53 \\
Noncollision transport crashes & 40.35 & 33.57 \\
Unspecified & 21.23 & 8.10
\end{tabular}

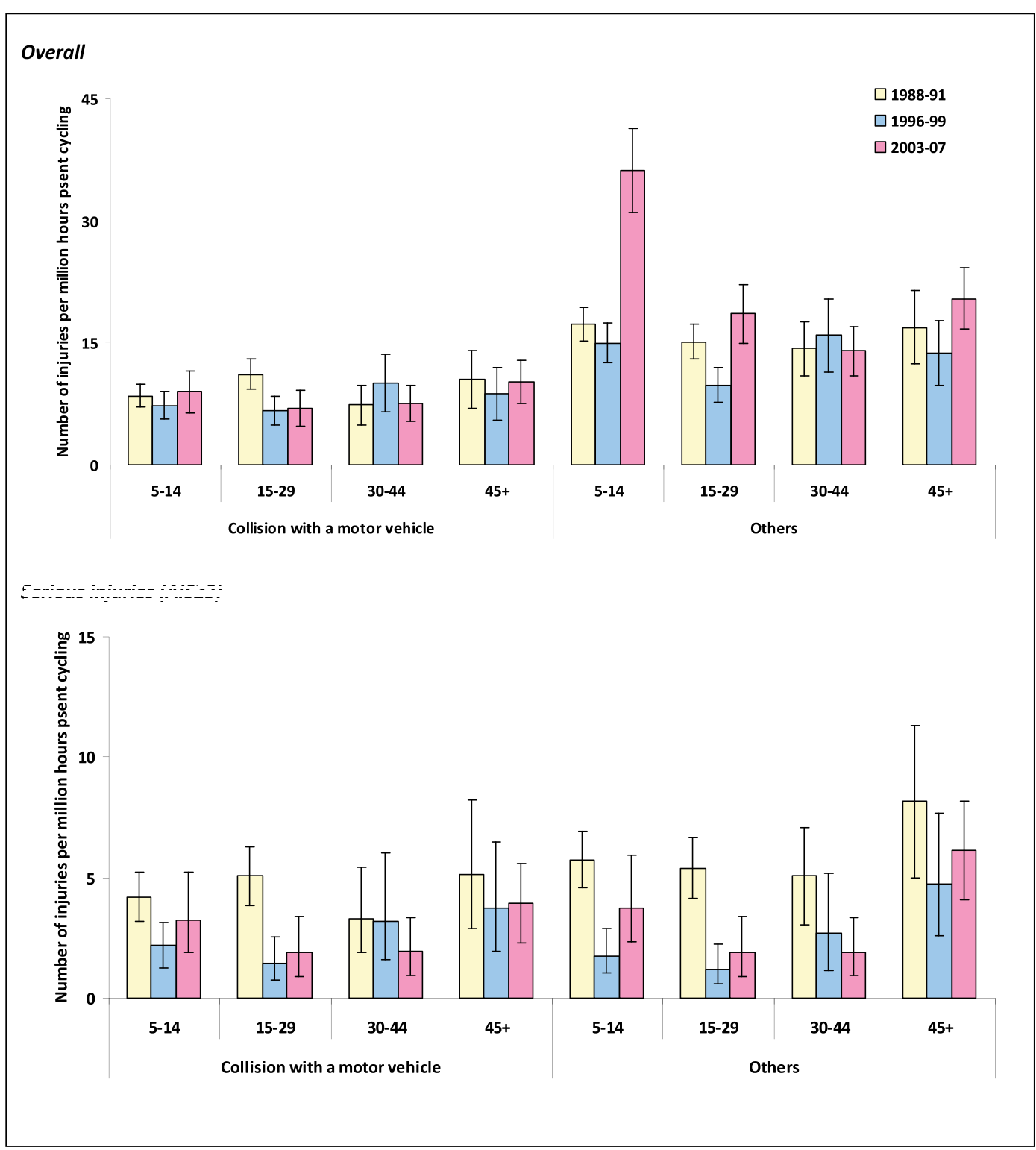

Figure 1 Annual rates of traffic injuries to pedal cyclists that resulted in death or hospital inpatient treatment by age. 


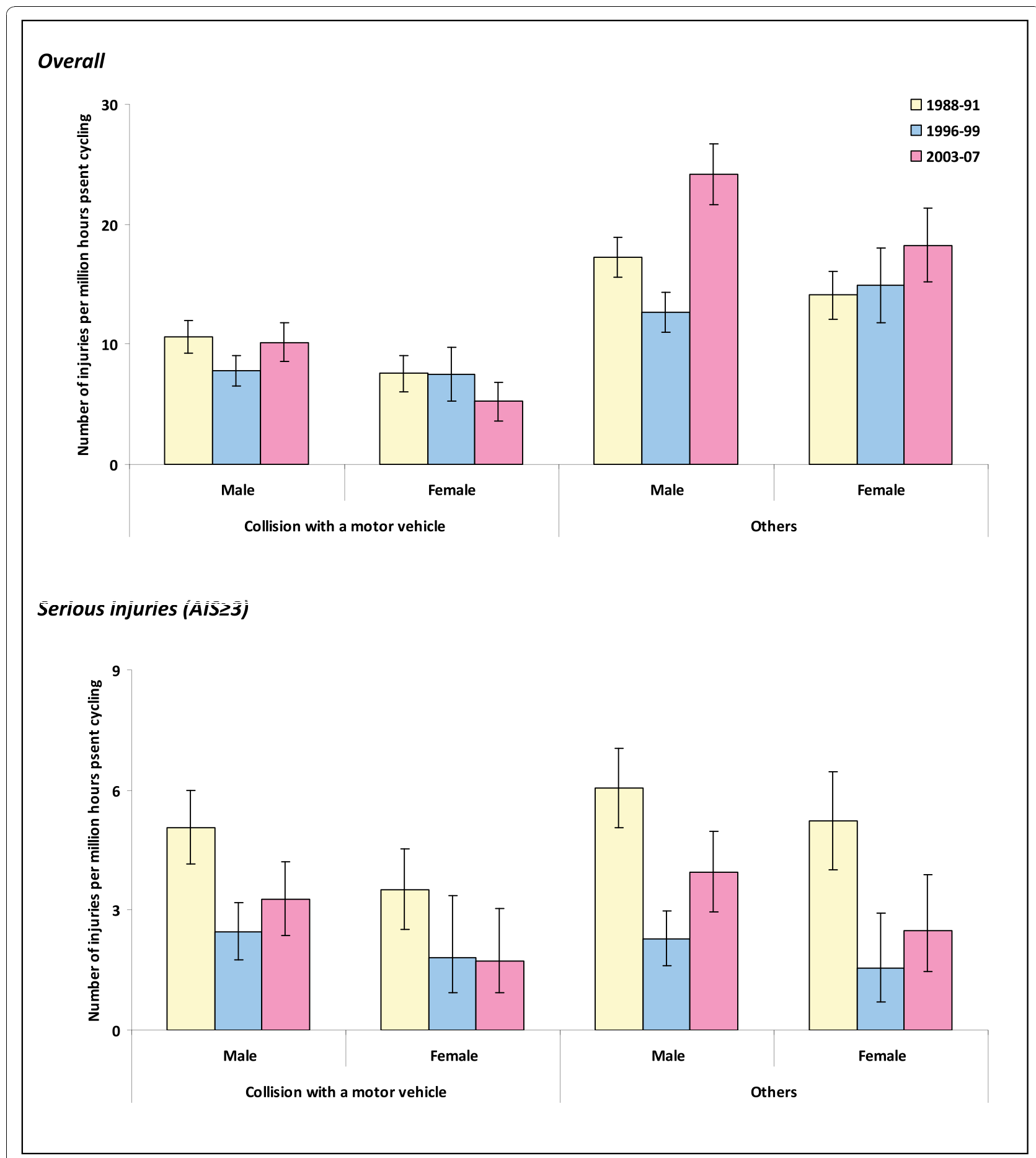

Figure 2 Annual rates of traffic injuries to pedal cyclists that resulted in death or hospital inpatient treatment by gender.

cause codes $[15,16]$. This could have a greater impact on time series analyses as the ICD9-CM was replaced with the ICD10-AM in 1999-2000. In addition, there were inconsistencies in the uploading of day cases to the National Minimum Dataset over time. To address this, we restricted the hospitalised sample to patients admitted for one day or more. It is also recognised that admission to hospital could be influenced by a number of factors including severity of injury, pre-existing comorbidities, access to hospital services, professional practice and bed/theatre availability [19]. In this analysis, there is the potential for misclassification of injury 


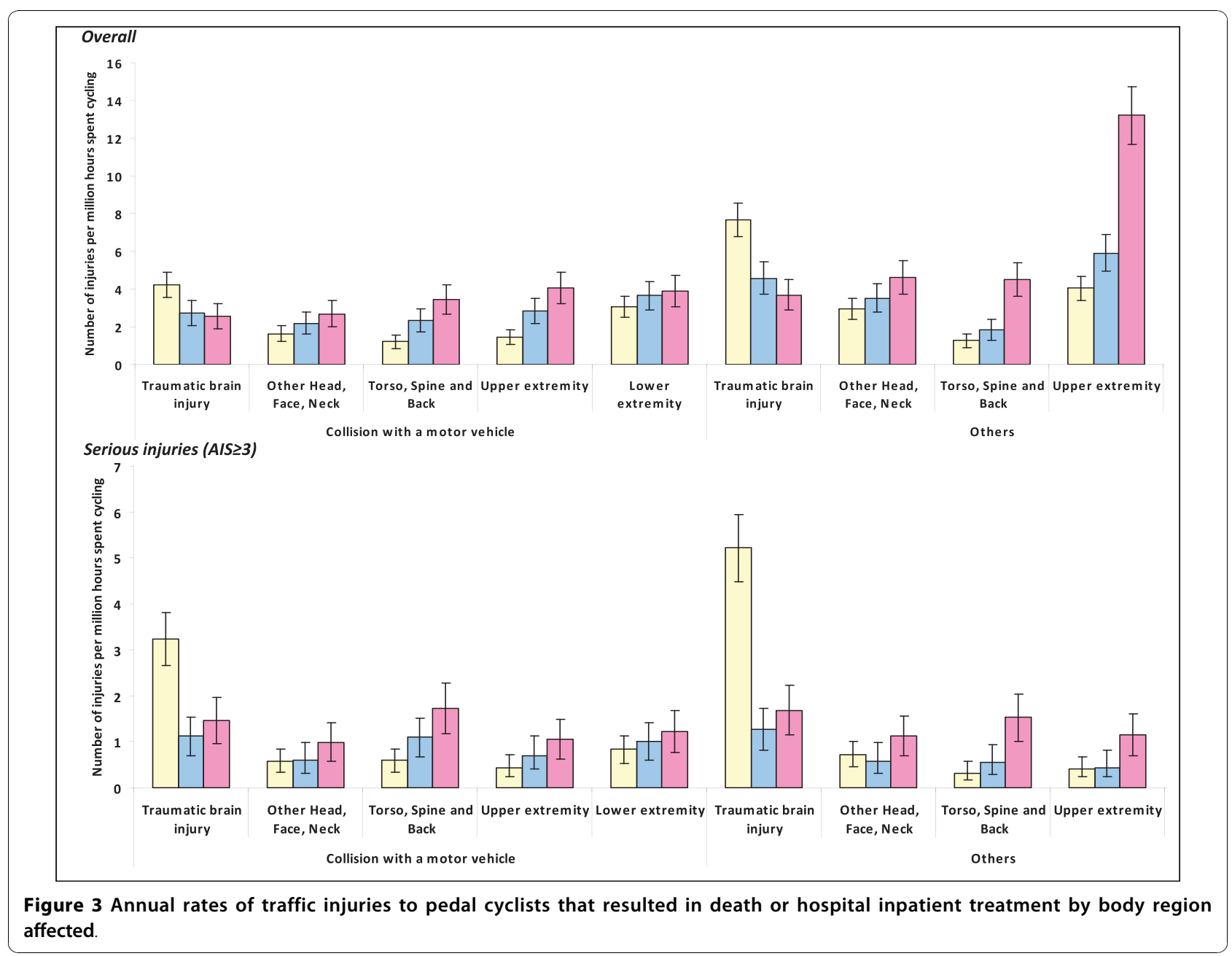

Table 4 Modified Barell body region by nature of injury diagnosis matrix for overall injuries (2003-07)

\begin{tabular}{|c|c|c|c|c|c|c|}
\hline Body Region Injured & Fracture & $\begin{array}{l}\text { Dislocation, } \\
\text { Sprains \& } \\
\text { Strains }\end{array}$ & Internal & $\begin{array}{l}\text { Open } \\
\text { wound }\end{array}$ & $\begin{array}{l}\text { Contusion/ } \\
\text { superficial }\end{array}$ & Others \\
\hline \multicolumn{7}{|c|}{ Percent of cyclists injured in crashes involving a collision with a motor vehicle } \\
\hline Traumatic brain injury & 6.48 & 0.00 & 29.05 & 0.00 & 0.00 & 0.00 \\
\hline Other Head, Face, Neck & 3.66 & 0.21 & 0.00 & 26.33 & 11.91 & 0.63 \\
\hline Spine and back & 12.64 & 2.93 & 1.25 & 0.00 & 0.00 & 0.00 \\
\hline Torso & 11.81 & 1.46 & 11.81 & 2.30 & 8.36 & 1.67 \\
\hline Upper extremity & 25.91 & 5.22 & 0.00 & 13.58 & 7.42 & 1.25 \\
\hline Lower extremity & 24.66 & 5.22 & 0.00 & 13.17 & 14.73 & 2.09 \\
\hline Others & 0.00 & 0.21 & 0.00 & 4.49 & 1.78 & 2.61 \\
\hline \multicolumn{7}{|c|}{ Percent of cyclists injured in other crashes } \\
\hline Traumatic brain injury & 2.50 & 0.00 & 14.90 & 0.00 & 0.00 & 0.00 \\
\hline Other Head, Face, Neck & 3.05 & 0.16 & 0.00 & 16.88 & 9.31 & 0.16 \\
\hline Spine and back & 3.33 & 1.35 & 0.59 & 0.00 & 0.00 & 0.00 \\
\hline Torso & 4.28 & 0.91 & 4.91 & 1.15 & 3.65 & 1.39 \\
\hline Upper extremity & 40.33 & 6.46 & 0.00 & 8.87 & 4.08 & 0.79 \\
\hline Lower extremity & 11.17 & 6.46 & 0.00 & 8.84 & 10.58 & 2.14 \\
\hline Others & 0.00 & 0.20 & 0.00 & 4.87 & 1.51 & 1.19 \\
\hline
\end{tabular}


Table 5 Modified Barell body region by nature of injury diagnosis matrix for serious injuries (2003-07)

\begin{tabular}{|c|c|c|c|c|c|c|}
\hline Body Region Injured & Fracture & $\begin{array}{c}\text { Dislocation, } \\
\text { Sprains \& } \\
\text { Strains }\end{array}$ & Internal & $\begin{array}{l}\text { Open } \\
\text { wound }\end{array}$ & $\begin{array}{l}\text { Contusion/ } \\
\text { superficial }\end{array}$ & Others \\
\hline \multicolumn{7}{|c|}{ Percent of cyclists with serious injuries (AIS $\geq 3$ ) } \\
\hline Traumatic brain injury & 11.25 & 0.00 & 28.16 & 0.00 & 0.00 & 0.00 \\
\hline Other Head, Face, Neck & 5.20 & 0.19 & 0.00 & 18.68 & 7.81 & 0.37 \\
\hline Spine and back & 8.36 & 2.42 & 2.51 & 0.00 & 0.00 & 0.00 \\
\hline Torso & 11.71 & 3.07 & 14.78 & 0.65 & 3.07 & 0.46 \\
\hline Upper extremity & 13.57 & 1.86 & 0.00 & 5.86 & 3.90 & 0.93 \\
\hline Lower extremity & 19.24 & 1.86 & 0.00 & 5.76 & 7.62 & 1.58 \\
\hline Others & 0.00 & 0.09 & 0.00 & 1.67 & 0.46 & 2.60 \\
\hline
\end{tabular}

severity due to the heterogeneity of the diagnostic categories included in the Barell matrix [31].

The estimates derived from the travel surveys may underestimate the total travel in New Zealand due to the exclusion of some people who travel a lot such as visitors, guests at hotels/motels, people who are not at home when surveyed and professional drivers (e.g., taxi and truck drivers). As relatively few bicycle trips were recorded compared to other modes, the cycling exposure information may be subject to a certain level of uncertainty. However, we did not anticipate any significant variation in accuracy of information collected over time as the same questions were used for all three surveys with high response rates although it is possible that the decrease in the response rate between the second and the third survey may impact on reliability of the data available.

Despite these limitations, the study presents some important findings to inform the development of road safety, injury prevention and trauma care programmes and services. Consistent with our findings, overseas research show that cyclists bear a higher risk than car drivers per time or distance travelled [32,33]. However, in a Dutch study, after adjusting for motorway journeys, nearly twice as many motorists are killed as cyclists per billion kilometres travelled and the probability of being admitted to hospital is similar for both modes of transport [34]. Although we were not able to control for biases such as differences in types of roads used by cyclists and drivers [33], our findings indicate that cyclists are likely to be at greater risk when travelling in the road environment of auto-centric countries like New Zealand.

The "safety in numbers" phenomenon suggests that the risk profile of cyclists may improve if more people cycle [35]. In New Zealand, the overall travel mode share for cycling declined steadily from $4 \%$ in 1989 to $1 \%$ in 2006 [36] while the annual distance driven in light 4-wheeled vehicles increased [37]. This may account for an increasing trend in the cycling injury rate in the last decade (in contrast to a steady decline in the injury rate of other road users) in our analysis. Despite this, cyclists have attracted relatively little attention in the road safety agenda. For example, the focus of the recently released "New Zealand's Road Safety Strategy" is on motorised transport [38].

We found that non-collision crashes accounted for two-fifths of the overall cycling injuries resulting in death or hospital inpatient treatment whereas collision with a motor vehicle accounted for almost two-fifths of serious cycling injuries. This extends previous research using emergency department data (reporting that 64$79 \%$ of crashes did not involve another vehicle [39-43]), hospital records (reporting that 30-66\% of crashes involved a motor vehicle [44-46]) and mortality data (reporting that $72-97 \%$ of crashes involved a motor vehicle [47-51]). Efforts to prevent cycling injuries could be more successful if factors associated with collisions are identified and targeted (e.g., traffic calming, providing cycle ways, improving cyclist conspicuity, driver education and training) alongside factors that are likely to impact on cyclist only crashes (e.g., improving road surface, cyclist skills training).

Of particular concern are children and adolescents who have experienced the greatest increase in the risk of cycling injuries despite a substantial decline in the amount of cycling over the past two decades. The travel surveys show that from $1989 / 90$ to $2005 / 08$, the average time spent cycling per week decreased from 28 minutes to 8 minutes among those aged 5-12 years and from 52 minutes to 12 minutes among those aged 13-17 years [7]. Likewise, from $1989 / 90$ to $2004 / 08$, cycling to school declined from $12 \%$ to $4 \%$ while being driven to school increased from $31 \%$ to $55 \%$ [7]. Parents' safety concern is one of the main reasons why children don't cycle or walk to school [52-54] although a wide range of factors can influence such behaviour [55]. If more children are driven to school, they will have less opportunity to develop cycling and road safety skills and traffic will be increased, posing more danger and initiating a 
vicious circle that can have an adverse impact on risks of injury as well as levels of physical activity. To address this, some initiatives have been developed in New Zealand, including the Walking School Bus Programme $[56,57]$, school-based cycle trains [58] and cyclist skills training [59].

Our analysis showed the declining trend in rates of traumatic brain injuries from 1988-91 to 1996-99. However, it is unclear whether this reflects the effectiveness of the mandatory all-age cycle helmet law implemented in January 1994 or simply reflects a general decline in all road injuries during that period. On the other hand, we found a steady increase in injuries to other body parts over the twenty year period. However, there is a relative dearth of research focusing on such injuries and potential protective measures such as extremity guards.

\section{Conclusions}

The burden of injuries to pedal cyclists is considerable and has been increasing over the last decade. A range of comprehensive strategies that can enhance bicycle safety, are required alongside strategies that promote cycling given its recognised health and environmental benefits.

\section{Acknowledgements}

We thank Mr Robert Hipkiss at the Ministry of Health for providing mortality and hospitalisation data, Ms Lynley Povey at the Ministry of Transport for providing Household Travel Survey data and Mr Brandon de Graaf at the Injury Prevention Research Unit, University of Otago for advising how to identify readmission cases.

\section{Author details}

${ }^{1}$ Section of Epidemiology and Biostatistics, School of Population Health University of Auckland, Auckland, New Zealand. ${ }^{2}$ School of Population Health, University of Auckland, Auckland, New Zealand.

\section{Authors' contributions}

STT has contributed to acquisition, analysis and interpretation of data and drafting the manuscript. AW and SA have contributed to interpretation of data and revising the manuscript critically. All authors have given final approval of the version to be published.

\section{Authors' information}

STT - MBBS, MPH, Research Fellow, Section of Epidemiology and Biostatistics, School of Population Health, University of Auckland, New Zealand AW - MBBS, PhD, FAFPHM, Professor and Head of School, School of Population Health, University of Auckland, New Zealand SA - MBChB, PhD, FAFPHM, Professor, Section of Epidemiology and Biostatistics, School of Population Health, University of Auckland, New Zealand

\section{Competing interests}

There is no conflict of interest including financial competing interest.

Received: 29 March 2010 Accepted: 30 October 2010 Published: 30 October 2010

\section{References}

1. Sport \& Recreation New Zealand: SPARC Facts '97-'01. Wellington: SPARC; 2007
2. Sport and Recreation New Zealand: Sport, recreation and physical activity participation among New Zealand adults: Key results of the 2007/08 Active NZ Survey. Wellington: SPARC; 2008.

3. New Zealand Bicycle Import Statistics. [http://www.bianz.org.nz/default. asp?PagelD=9326].

4. New Zealand motor vehicle registration statistics. [http://www.nzta.govt. nz/resources/motor-vehicle-registration-statistics/].

5. Ministry of Transport: Comparing travel modes. Household Travel Survey v2 revised Nov 2009. Wellington: Ministry of Transport; 2010.

6. Tin Tin S, Woodward A, Thornley S, Ameratunga S: Cycling and walking to work in New Zealand, 1991-2006: regional and individual differences, and pointers to effective interventions. Int J Behav Nutr Phys Act 2009, 6(1):64.

7. Ministry of Transport: How New Zealanders travel: trends in New Zealand household travel 1989-2008. Wellington: Ministry of Transport; 2009.

8. Cyclists' Touring Club (CTC): Barriers to cycling: Perspectives from existing and potential cyclists. Godalming: CTC; 1997.

9. Pearce L, Davis A, Crombie H, Boyd H: Cycling for a healthier nation. Berkshire: Transport Research Laboratory; 1998.

10. Ministry of Transport: Cyclists: Crash Fact Sheet. Wellington: Ministry of Transport; 2009.

11. Langley JD, Dow N, Stephenson S, Kypri K: Missing cyclists. Inj Prev 2003, 9(4):376-379.

12. Dow N, Langley J, Kypri K, Casey D: Trends in cyclist injury. Dunedin: Injury Prevention Research Unit, University of Otago; 2001.

13. Barell V, Aharonson-Daniel L, Fingerhut LA, Mackenzie EJ, Ziv A, Boyko V, Abargel A, Avitzour M, Heruti R: An introduction to the Barell body region by nature of injury diagnosis matrix. Inj Prev 2002, 8(2):91-96.

14. International Classification of Disease (ICD). [http://www.who.int/ classifications/icd/en/].

15. Langley J, Stephenson S, Thorpe C, Davie G: Accuracy of injury coding under ICD-9 for New Zealand public hospital discharges. Inj Prev 2006, 12(1):58-61.

16. Davie G, Langley J, Samaranayaka A, Wetherspoon ME: Accuracy of injury coding under ICD-10-AM for New Zealand public hospital discharges. Inj Prev 2008, 14(5):319-323.

17. Johansson LA, Westerling R: Comparing hospital discharge records with death certificates: Can the differences be explained? J Epidemiol Community Health 2002, 56(4):301-308.

18. Langlois JA, Smith GS, Baker SP, Langley JD: International Comparisons of Injury Mortality in the Elderly: Issues and Differences between New Zealand and the United States. Int J Epidemiol 1995, 24(1):136-143.

19. Cryer $C$, Langley J: Developing indicators of injury incidence that can be used to monitor global, regional and local trends. Dunedin: Injury Prevention Research Unit, University of Otago; 2008.

20. New Zealand Household travel Survey. [http://www.transport.govt.nz/ research/TravelSurvey/]

21. Langley J: Experiences using New Zealand's hospital based surveillance system for injury prevention research. Methods Inf Med 1995, 34(4):340-344.

22. Langley J, Stephenson S, Cryer C, Borman B: Traps for the unwary in estimating person based injury incidence using hospital discharge data. Inj Prev 2002, 8(4):332-337.

23. Civil I, Twaddle B: Trauma care systems in New Zealand. Injury 2003, 34(9):740-744.

24. Ahlbom A: Biostatistics for Epidemiologists Stockholm: Lewis Publishers; 1993.

25. Aharonson-Daniel L, Boyko V, Avitzour M, Ziv A, Peleg K: Proposed methodology for building multiple injury profiles (MIP). In Proceedings of the international collaborative effort on injury statistics Vol IV: 2003; Hyattsville, MD. Edited by: Fingerhut LA. Centers for Disease Control, National Center for Health Statistics; 2003:1026.

26. Aharonson-Daniel L, Boyko V, Ziv A, Avitzour M, Peleg K: A new approach to the analysis of multiple injuries using data from a national trauma registry. Inj Prev 2003, 9(2):156-162.

27. Aharonson-Daniel L, Giveon A, Peleg K: Gaps in injury statistics: multiple injury profiles reveal them and provide a comprehensive account. Inj Prev 2005, 11(4):197-200.

28. Committee on Medical Aspects of Automotive Safety: Rating the Severity of Tissue Damage: I. The Abbreviated Scale. JAMA 1971, 215(2):277-280. 
29. Association for the Advancement of Automotive Medicine: The Abbreviated Injury Scale: 1990 Revision, Update 98 Barrington, IL: Association for the Advancement of Automotive Medicine; 1998.

30. Clark DE, Ahmad S: Estimating injury severity using the Barell matrix. Inj Prev 2006, 12(2):111-116.

31. Cryer C: Severity of injury measures and descriptive epidemiology. Inj Prev 2006, 12(2):67-68

32. Wardlaw M: Assessing the actual risks faced by cyclists. Traffic Eng Contr 2002, 43(11):420-424

33. Cavill N, Davis A: Cycling and Health: What's the evidence? London: Cycling England; 2007.

34. Ministry of Transport, Public Works and Water Management: The Dutch Bicycle Master Plan: Description and evaluation in an historical context. Den Haag: Ministry of Transport; 1999.

35. Jacobsen PL: Safety in numbers: more walkers and bicyclists, safer walking and bicycling. Inj Prev 2003, 9(3):205-209.

36. Ministry of Transport: Sustainable and safe land transport: trends and indicators. Wellington: Ministry of Transport; 2007.

37. Ministry of Transport: Driver travel in cars, vans, utes and SUVs. Household Travel Survey v2 revised Dec 2009. Wellington: Ministry of Transport; 2010.

38. Ministry of Transport: Safer Journeys. New Zealand's Road Safety Strategy 2010-2020. Wellington: Ministry of Transport; 2010.

39. Meuleners LB, Lee AH, Haworth C: Road environment, crash type and hospitalisation of bicyclists and motorcyclists presented to emergency departments in Western Australia. Accid Anal Prev 2007, 39(6):1222-1225.

40. Scott D, Hockey R, Barker R: Bicycle injury in Queensland. Injury Bulletin $2005,86$.

41. Davidson JA: Epidemiology and outcome of bicycle injuries presenting to an emergency department in the United Kingdom. Eur J Emerg Med 2005, 12(1):24-29.

42. Stutts JC, Hunter WW: Motor vehicle and roadway factors in pedestrian and bicyclist injuries: an examination based on emergency department data. Accid Anal Prev 1999, 31(5):505-514.

43. Jacobson GA, Blizzard L, Dwyer T: Bicycle injuries: road trauma is not the only concern. Aust N Z J Public Health 1998, 22(4):451-455.

44. Richter M, Otte D, Haasper C, Knobloch K, Probst C, Westhoff J, Sommer K, Krettek C: The current injury situation of bicyclists-a medical and technical crash analysis. J Trauma 2007, 62(5):1118-1122.

45. Boström $L$, Nilsson $B$ : A review of serious injuries and deaths from bicycle accidents in Sweden from 1987 to 1994. J Trauma 2001, 50(5):900-907.

46. Zavoski R, Lapidus G, Lerer T, Banco L: Bicycle injury in Connecticut. Conn Med 1995, 59(1):3-9.

47. Missoni E, Kern J: Fatality risk factors for bicyclists in Croatia. Croat Med J 2003, 44(5):610-613.

48. Rowe BH, Rowe AM, Bota GW: Bicyclist and environmental factors associated with fatal bicycle-related trauma in Ontario. Can Med Assoc $J$ 1995, 152(1):45-53

49. Ostrom M, Bjornstig U, Naslund K, Eriksson A: Pedal cycling fatalities in northern Sweden. Int J Epidemiol 1993, 22(3):483-488.

50. Gilbert K, McCarthy M: Deaths of cyclists in London 1985-92: the hazards of road traffic. Br Med J 1994, 308(6943):1534-1537.

51. Hawley DA, Clark MA, Pless JE: Fatalities involving bicycles: a non-random population. J Forensic Sci 1995, 40(2):205-207.

52. Wen LM, Fry D, Rissel C, Dirkis H, Balafas A, Merom D: Factors associated with children being driven to school: implications for walk to school programs. Health Educ Res 2008, 23(2):325-334.

53. Kerr J, Rosenberg D, Sallis JF, Saelens BE, Frank LD, Conway TL: Active Commuting to School: Associations with Environment and Parenta Concerns. Med Sci Sports Exerc 2006, 38(4):787-793.

54. Timperio A, Crawford D, Telford A, Salmon J: Perceptions about the local neighborhood and walking and cycling among children. Prev Med 2004, 38(1):39-47.

55. Davison KK, Werder JL, Lawson CT: Children's active commuting to school: current knowledge and future directions. Prev Chronic Dis 2008, 5(3):A100

56. O'Fallen C: Walking School Bus Networks: Evaluation of Trial in Christchurch. Wellington: Pinnacle Research; 2001.

57. Kearns RA, Collins DCA, Neuwelt PM: The Walking School Bus: Extending Children's Geographies? Area 2003, 35(3):285-292
58. O'Fallen C: Developing school-based cycle trains in New Zealand. Land Transport New Zealand Research Report 338. Wellington: Land Transport New Zealand; 2007.

59. NZ Transport Agency: Cyclist skills training: a guide for the set-up and delivery of cyclist training in New Zealand. Wellington: NZ Transport Agency; 2008.

\section{Pre-publication history}

The pre-publication history for this paper can be accessed here: http://www.biomedcentral.com/1471-2458/10/655/prepub

doi:10.1186/1471-2458-10-655

Cite this article as: Tin Tin et al:: Injuries to pedal cyclists on New Zealand roads, 1988-2007. BMC Public Health 2010 10:655.

\section{Submit your next manuscript to BioMed Central and take full advantage of:}

- Convenient online submission

- Thorough peer review

- No space constraints or color figure charges

- Immediate publication on acceptance

- Inclusion in PubMed, CAS, Scopus and Google Scholar

- Research which is freely available for redistribution

Submit your manuscript at www.biomedcentral.com/submit
C) Biomed Central 